\title{
CREATING THE NEW ECOLOGICAL ORDER? \\ ELIAS AND ACTOR-NETWORK THEORY
}

\author{
Paper number 01/01
}

\author{
TIM J. NEWTON \\ University of Exeter
}

\begin{abstract}
This article provides a critique of current work on the 'greening' of organizations, especially that drawing on 'ecocentric' argument. It questions the meaning of 'nature' and uses studies of the sociology of order and networks to debate the assumptions of current green discourse and its normative rationales. The article advances an 'interdependency network' perspective, applying it to the greening of organizations, green technologies and issues of globalization. It argues that this perspective offers an alternative theoretical rationale and a potential basis for future research.
\end{abstract}

School of Business and Economics, Streatham Court, Rennes Drive

Exeter, EX4 4PU, UK Phone: +44 1392263221 Fax: +44 1392264425

E-mail: T.J.Newton@exeter.ac.uk 
ISSN No: 14732939 


\section{INTRODUCTION}

This article provides a critique of current approaches to the 'greening' of organizations, particularly that drawing on ecocentric argument. It then advances an interdependency network' perspective as an alternative theoretical rationale and basis for research, illustrating this perspective through reference to green organizational processes, green technologies and globalization.

The greening of organizations is intertwined with the broader project of greening societies. This project represents, in effect, a quest for a 'new ecological order' where sustainable practices replace those that occasion environmental degradation. Yet the question arises as to whether it is possible to create 'new orders', whether ecological or otherwise. As John Law implies, visions of a new order have rarely been realized as intended:

'How many generals have seized power in order to "clean things up"? ...

How often have we heard that Communism, or Socialism, or free-market economics, or cost-benefit analysis, or monetarism would bring the good life (for those who remained) if only they were systematically imposed and all the deviant elements were rooted out? (1994: 6)

Visions of a new ecological order can be readily found within current green literature and organizational 'greening' literature. Jonathan Porritt and David Winner provide an example of the former with their argument that the 'Green Movement' should seek:

'.. nothing less than a non-violent revolution to overthrow our whole polluting, plundering and materialistic industrial society and, in its place, to create a new economic and social order which will allow human beings to live in harmony with the planet' (1988: 9, added emphasis)

Richard Welford provides an example from the organizational literature concerned with greening through his argument that 'we must challenge the existing order' (1997a: 14). 
Such is his commitment to the new ecological order that he exhibits a clear desire to 'root out deviant elements' (cf., Law, 1994, above) who do not share this vision:

'If there are members of management or the workforce who are not convinced of the need for ecological management strategies then they must be motivated to change' (Welford, 1995: 146, added emphasis)

A desire to re-order relationships with the natural environment can be observed elsewhere in the green organizational literature, albeit not always in quite such a totalizing manner as Welford prescribes. For instance, Paul Shrivastava argues for 'a fundamental reversal in the focus of managers' attention' (1995: 123) toward an 'ecocentric management' paradigm (1995: 127ff), and Param Skrikantia and Diana Bilmoria seek the replacement of the 'dominant corporate paradigm' by an 'alternative sustainability paradigm' (1997: 394). In a similar fashion, David Cooperrider and Gurudev Khalsa argue for 'a new paradigm in our way of relating to our environment' (1997: 335) and Ronald Purser suggests 'a fundamental change in cultural perception' (1997: 362). Such language directly echoes the argument of deep ecologist and ecocentric writers who demand 'a new ecological paradigm' (Capra, 1995: 20). The present article seeks however to question this and other conceptions of a new green order, and of the manner of its achievement. In so doing, I will draw on the sociology of order and networks, particularly the work of Norbert Elias and Michel Callon.

The main focus of this article is on the feasibility of the 'eco-ordering' project. Realizing a new 'eco-order' is unlikely to occur just because people perceive an impending ecological crisis. As Andrew Dobson notes:

'The general political-ecological position that the environmental crisis will eventually be suffered by everybody on the planet, and that therefore the ideology's appeal is universal, has been perceived as a source of strength for the Green movement ... [Yet] this may be the movement's basic strategic political error because the universality appeal, is properly speaking, Utopian. It is simply untrue to say that, given present conditions, it is in everybody's interest to bring about a sustainable and egalitarian society. A significant and influential proportion of society, for example, has a material interest in prolonging the environmental crisis because there is money to be made from administering it' (1990: 152). 
The difficulties of the eco-ordering project become even more pronounced once we view it from a global perspective. Steven Yearley notes that:

'As Dobson correctly points out, it is utopian to suppose that there will be consensus on environmentally far-reaching reforms even within the context of an industrial nation. How much more unrealistic then is the assumption that global problems will call forth a unified international response, across all the disparities of wealth, geography, religion and ethnicity of the globe' (1996: 79).

Such highlighting of the problems of creating a new green 'promised land' may be seen as 'negative' by some in relation to the 'green cause' because underlining the difficulties may encourage pessimism rather than optimism. I would argue however that such a position is preferable to that of a 'feel good' optimism based on shallow argument.

Not all ecocentric writers assume that there is a single path to a 'green' redemption. On the one hand there are writers, including those writing on organizations, who champion 'total solutions' that human beings must follow if they are to save the planet. They base their argument on a perception that 'needs must': that is to say, given a supposedly immanent environmental Armageddon, a total and totalizing strategy toward a 'new ecoorder' is required wherein all members of organizations 'must be motivated to change' (Welford, 1995: 147, added emphasis). On the other hand, some deep ecologists argue that a more pluralistic view is required because it is unlikely that we can arrive at uniform agreement on the 'green agenda' (Naess, 1992, 1995a). Others sympathetic to deep ecology try to reconcile the modernist thinking of deep ecology with postmodernism and poststructuralism (Zimmerman, 1994).

Yet whether totalistic, pluralistic, or even postmodernist, deep ecologists seek variants of new eco-orders where the environmentally degrading patterns of past industrial society are replaced by activities which protect rather than destroy the planet. The question remains however as to how such projects can be achieved. As John Law (1994) notes, other 'new orders', whether fascism, communism, or free market liberalism, have 
floundered, and their desire to deliver supposed 'goods' (e.g., racial purity, equality, enterprise) have occasion a variety of 'bads' (e.g., genocide, inequality, oligopoly). Similarly, questions arise with the project of a new eco-order. Just as the promised 'goods' of industrial society (e.g., material prosperity) have occasioned a variety of 'bads' (e.g., environmental degradation; Beck, 1992; Adam, 1998), so the ecocentric dreams of deep ecologists have been seen by some as the stuff of nightmares (e.g., 'eco-fascism', misanthropy, or a pessimistic risk-averse society). Though such critique can be questioned, we need to examine to what ends ecocentrics 'use' nature, and whether those ends are achievable.

The particular concern in this article is with organizational literature on greening and ecology. Though sympathetic to the green cause, I believe that there are a number of limitations with existing work in this field. I shall focus on organizational writers who espouse 'deep green' values and who adopt an 'ecocentric' approach because (1) they represent a challenge to traditional management approaches to organizations and to reform environmentalism and, (2) they have generated increasing interest within green organization studies (see below) and (3) they often envisage a radical re-ordering of industrial society through the promotion of ecocentric values. I will argue that such writers have however failed to appreciate the immense difficulties of shifting to a new green paradigm, a failure that is partly conditioned by the problems inherent in creating any 'new order'. As a writer sympathetic to deep ecology notes, 'deep ecologists ... have not examined sufficiently the enormity of the obstacle impeding such a [paradigm] shift' (Zimmerman, 1994: 54).

To illustrate the difficulties in ecocentrically re-ordering the planet, I shall explore the sociology of order and ordering, particularly that of Elias and Callon. I will suggest that this work provides an alternative perspective through which research in this area might advance. In particular, I shall argue that a focus on interdependency networks can aid researchers understanding of organizations and ecology. Such work challenges the argument that organizations should shift to strong green cultures (see below). Instead it 
suggests that it is more productive to research the configuration of interdependent networks which support or impede greening processes. In exploring this argument, I will examine the interrelation between the concept of the actor and the networks that surround environmental degradation. In addition, I shall address the challenges in building global green networks. In so doing, I aim to move beyond earlier critique (e.g., Newton and Harte, 1997) toward a framework for research on ecology and organizations. I must stress however that my aim is to indicate a possible research direction rather than deliver a fully elaborated research platform.

I shall firstly explore the form in which ecocentrism has been applied within organization studies and then question ecocentric assumptions.

\section{THE NEW ECOCENTRISM IN ORGANIZATION STUDIES}

In recent academic writing there has been an increasing questioning of the relevance of 'traditional management paradigms' to 'green' organization studies (Newton and Harte, 1997). At the same time, a number of ecocentric writers have argued that the consideration of ecological concerns requires a paradigm shift in management studies. For example, Callenbach et al. (1993), Welford (1995), Shrivastava (1995), Purser et al. (1995), Purser (1997), Srikantia and Bilimoria (1997) and Cooperrider and Khalsa (1997) have called for the abandonment of the traditional management paradigm because it is perceived as either insufficiently attentive, or antithetical, to ecological concerns. It is suggested that the traditional management paradigm exhibits an anthropocentric attitude wherein nature is seen as a resource to be used and exploited by humans (Shrivastava, 1995; Purser et al., 1995). This is reflected in a 'focus on production [which] ignores the

destructive aspects of organizations' (Shrivastava, 1995: 125). Writers who adopt a traditional management paradigm are criticized for using 'reactive strategies' (Welford, 1995: 21) which reduce sustainable development to 'technological fixes, or incremental market-price corrections' (Purser, 1997: 362; cf., Welford, 1995: 21). In place of these traditional paradigms, ecocentric organizational writers argue for an 'attitude of reverence for life' (Purser et al., 1995: 1073). A new paradigm is advanced which emphasizes 
ecological harmony and 'postpatriarchal values' that 'seek freedom from domination of all types', especially 'human domination over nature' (Shrivastava, 1995: 130). Drawing on the ethics of deep ecology, there is an emphasis on interdependencies within the biosphere and the way in which 'each species and biological organism depends on a web of relationships with its ecosystem' (Purser et al., 1995: 1073). At the organizational level, ecocentric writers suggest 'a shift in values within the corporate culture from domination to partnership, from the ideology of economic growth to that of ecological sustainability' (Callenbach et al, 1993, quoted in Welford: 1995: 86). These writers may draw on a range of organization theory resources, such as work on culture (e.g., Callenbach et al, 1993), strategy (e.g., Welford, 1995), and institutional theory (Srikantia and Bilimoria, 1997) but they share a common sympathy for ecocentric ethics.

Though not the dominant paradigm, there has been significant interest in ecocentrism amongst organizational writers, reflected in management journals such as the Academy of Management Review (e.g., Gladwin et al, 1995; Purser et al., 1995; Shrivastava, 1995), as well as journals focused on the natural environment such as Organization \& Environment (e.g., Cooperrider and Khalsa, 1997; Purser, 1997; Srikantia and Bilimoria, 1997). Even among writers who do not explicitly define themselves as ecocentric, there is a growing acknowledgement of the significance of ecocentric argument. For instance, Pratima Bansal and Kendall Roth argue that the tension between ecocentric and anthropocentric approaches ... is a critical dialogue in organization studies' (2000: 733; cf., Andersson and Bateman, 2000: 553). However whether in spite of, or because of, this increasing interest, there has been very limited questioning of its precepts within the green organizational literature. Given the developing attention to ecocentric thought in organization studies, it becomes important to critically examine the ecocentric representation of nature and the coherence of ecocentric management methods. 


\section{QUESTIONING ECOCENTRISM}

\section{Representing Nature}

How people in the West have seen nature has varied considerably over recent centuries, from the mediaeval depiction of nature in the 'Great Chain of Being', to Enlightenment distancing and 'progress over' nature, to Romanticist desires for human re-integration with nature, to counter-Romanticist 'denunciations of the quest for humanist redemption through "nature" (Soper, 1995: 32) ranging from Baudelaire and Oscar Wilde to Foucault. With this very broad discursive heritage (just in the West), it does seem remarkable how simplistically notions of nature are sometimes treated within 'green' literature, ecocentric or otherwise. There is a tendency to fall back on romanticist beliefs, idealizing the 'innocence' of pre-industrial hunter-gatherer societies where life was supposedly 'shared with the bird, bear, insects, plants, mountains, clouds, star, sun' (Steiner, 1976: 113, quoted in Sessions, 1995: 158; cf., Glendinning, 1995). Yet as Eric Darier notes,

"justifying human actions in the name of "nature" leaves the unresolved problem of whose (human) voice will be legitimate to speak for "nature" (1999: 24). As Soper comments, "romantic conceptions of "nature" as wholesale salvation from cultural decadence and racial degeneration were crucial to the construction of Nazi ideology' (1995: 32). As Zimmerman observes, though deep ecology may not lead to 'eco-fascism', there are 'some disturbing parallels between Nazi rhetoric and the claims made by deep ecologists' (Zimmerman, 1994: 173-174). In sum, work such as that of Soper, Darier and Zimmerman suggests that our notions of nature are open to contestation and dispute ${ }^{i}$.

Other writers, including Al Gore (1992: 217), have questioned whether ecocentrism is fundamentally misanthropic because of its desire to remove 'the privileged position of humans as the sole locus of value' (Purser et al., 1995: 1073) and live in 'harmony with nature' (Shrivastava, 1995: 131, table 1; Srikantia and Bilimoria, 1997: 395, table 4). Critics argue that such ecocentrism tends toward an idealized view of nature which assumes that we can somehow give equality to 'pathogenic microbes, animal vectors of 
lethal diseases' (Bookchin, 1994: 22). Tim Luke argues that an 'ecocentric' would 'be bound ethically to save a California condor hatchling over a human child, because the former - given its rarity - is much more valuable' (1988: 87).

Eco-writers might counter such arguments by suggesting that they are frequently polemical in tone, and selective in the treatment of environmental information. For example, contrary to Murray Bookchin and Tim Luke, some deep ecologists do argue that 'in situations involving vital interests ... humans have ... overriding obligations towards their own kind' (Naess, 1995b: 76; cf., Sessions, 1995a: 157). However the problem with such counter-argument is that it is the rather polemical tone of many green writers (Cheney, 1989) that invites the counter-polemic of writers like Bookchin. In addition, the ecocentric desire to try to promote species equality does remain questionable. As Judith Green (1995) argues, this desire for 'bio-equality' reflects a misguided and decontextualised liberalism which projects human concerns on to natural processes which are not inherently equal (cf., Zimmerman, 1994). To take just one example, contrary to Disney World, carnivores don't usually consult herbivores before they eat them.

Other difficulties surround central tenets of ecocentric discourse. For instance, Ned Hettinger and Bill Throop (1999) question the ecocentric emphasis on the stability and 'fragile balance' of ecosystems because it is contradicted by ecological science studies which suggest that nature is frequently characterized by instability and flux (as reflected in weather patterns, population fluctuations etc.). Similarly, another key ecocentric belief is 'that our finite Earth places limits on our industrial growth' (Dobson, 1990:173). Yet as Ted Benton argues, 'it is a mistake ... to think of "Nature" as a finite system of constraints which sets outer limits to human demands' (1994: 43). Human beings have highly developed linguistic and technological abilities (Elias, 1991, Benton, 1994) which enable considerable flexibility with respect to 'nature'. Such plasticity questions the belief that nature is absolutely finite with respect to human beings (cf., Bradford, 1989). This does not imply that we can 'use and abuse' nature but that we lack clear boundaries in our relationship with the natural world. 
Such argument challenges central aspects of ecocentric thought. Yet its nuances have not generally impacted upon the green organizational literature. Furthermore, as we shall see in the next section of this article, the paradigm shift rationales of ecocentric organizational writers have a tendency to rely for their enactment on either (1) evangelical imploration and/or (2) concepts derived from and rooted in the traditional management paradigm'.

\section{Normative Rationales}

Newton and Harte (1997) have noted that the evangelical spirit of the green organizational literature is betrayed by a linguistic dependency on the transitive verb, 'must', with its use generally signifying a reliance on imploratory argument. This same comment also applies to ecocentric writers. For example, Purser et al tell us that 'both theorists and practitioners must confront the [ecological] issue' within an 'ecological democracy' 'based on a mutual assumption that resources must be shared' (1995: 1080, added emphasis), and 'designed in accordance with the highest ideals of their members' (1995: 1081). Similarly Welford (1995) asserts that 'there must be clear limits to consumerism (1995: 17, added emphasis) and 'we must increasingly recognise the benefits of acting cooperatively rather than competitively' (1995: 22, added emphasis). John Dryzek argues that this idealism is also common with eco-philosophies beyond ecocentrism and deep ecology (such as eco-feminism, or anti-consumption philosophy). As Dryzek notes, 'in saying what should transpire, [eco-philosophers] generally pay little heed to what can transpire ... This inattention means that advocacy of these alternatives is

often reduced to wishful thinking' (1996: 30, original emphasis). Yet following Newton and Harte (1997), we 'must' question whether 'eco-change' will happen just because particular writers feel it 'must' happen. As Dobson (1990) and Yearley (1996) note, there are incredible obstacles to enacting a new eco-order committed to replacing competitiveness and consumption with cooperation and material restraint. 
Such obstacles mean that it is unlikely that the green endeavor will be realized through evangelical rhetoric alone (Newton and Harte, 1997). Nevertheless such rhetoric could perhaps be justified if it were accompanied by convincing rationales that answer the question of 'how' organizational and societal 'eco-change' is to be achieved. Such a project would meet Luke's (1988) criticism that ecocentrism and deep ecology lack a practical program. Yet when we approach this issue there is a strange irony in some of the prescriptions of ecocentric organizational writers. For though they are critical of the traditional management paradigm, their proposed ecocentric solutions can nevertheless remain couched in traditional managerial concepts and language. For instance, ecocentric writers have championed culture change as a central plank of ecocentric strategy (e.g., Welford, 1995: 21, 82; Shrivistava, 1995: 131, Callenbach et al, 1993: 66, 77), drawing on promoters of culture change such as Deal and Kennedy (1988). This turn to corporate culture can appear attractive given its promised ability to enroll all organizational members as culturally 'green', and possibly ecocentric, agents. Yet there are a number of difficulties with its advocacy. Firstly, the culture change literature is in something of a crisis, with writers no longer just questioning the validity of culture change as area of study (e.g., Smircich, 1983) but actively questioning its continuing relevance to organizational analysis (e.g., Ogbonna, 1993). Secondly, with some exceptions (e.g., Jones and Welford, 1997), green organizational writers have adopted the messages of corporate culture discourse (e.g., Elkington and Burke, 1997; Callenbach et al., 1993; Gray et al., 1993; Shrivastava, 1995), rather than the symbolic interpretive treatment which stresses culture as metaphor (Smircich, 1983; Anthony, 1994). Ironically it is the corporate culture field that remains the element of organizational culture studies most closely interrelated with a traditional management paradigm(e.g., Deal and Kennedy, 1988). And though such corporate culture change programs are relevant to the change of values desired by deep ecologists and ecocentric organizational writers, the reality of their enactment can reveal a very traditional concern with the manipulation and control of employees, reflecting a 'desire to bind employees' hearts and minds to the corporate interest' (Kunda, 1992: 218). Such 'normative control' offers the potential to deliver the new order which ecocentric writers desire, but not necessarily in terms of the 'post- 
patriarchal' values of 'liberation', 'anti-domination' 'cooperation', 'creativity' which they elsewhere espouse. Instead, for those who argue that culture change programs engender 'nascent totalitarianism' (Willmott, 1993: 523), the appeal to 'eco-culture change' is likely to reinforce the charge that ecocentrism invites 'eco-fascism'.

It is beyond the scope of the present article to undertake a more wide ranging critique of current 'eco-change' rationales within the green organizational literature. However as Newton and Harte (1997) note, the problems noted above are not unique to green culture change. More generally, the ecocentric critique of traditional environmental management paradigms tends to be somewhat insensitive to the limitations and inconsistencies of ecocentric discourse. At the same time, ecocentric writers do not always appear sufficiently aware of the divorce between the values they proselytize and the management programs they endorse.

Given such difficulties, the question remains as to what can be done to move toward a situation wherein organizations and societies are more likely to act in an ecologically supportive manner. I shall now address this question. I will firstly examine the 'interdependency network' perspective, with particular attention to the work of Elias and Callon. I shall then explore the networked nature of environmental degradation and the significance of how we conceive of the actor within such networks. Finally, I will consider the implications of global networks for organizational research.

\section{NATURE, ORDERING AND NETWORKS}

'The management of an (always partial) order is, therefore, always incomplete, less than perfect and bound to remain so. There are many outer dependencies and unaccounted-for human purposes and drives which ... interfere with the designs of the managers. The planned and managed sector remains no more than a shack erected on moving sands ... At best, we can speak of islands of (temporary and fragile) order scattered over the vast sea of chaos (that is, the unplanned and undesigned flow of events)' (Bauman, 1990: 183) 
For Zygmunt Bauman, any sense of order, whether economic or ecological, is always partial and temporary. The initial logic of his argument is quite simple, and derives from the observation that 'all power has its limits, as control over the universe as a whole is beyond human potential and eludes even the most audacious of human dreams' (1990: 184-185). In consequence, it remains difficult for any individual or group to create a permanent order with 'all the deviant elements .. rooted out? (Law, 1994: 6, see above). John Law argues that as a result we should speak of 'ordering' because 'orders are never complete' but 'more or less precarious and partial accomplishments that may be overturned' (1994: 1-2). Following Law, we can only speak of frail attempts at 'ecoordering' rather than entertain a false dream of a 'pure' 'eco-order'.

To further explore why the creation of order remains tenuous, it is helpful to go back to the earlier writing of Norbert Elias. For Elias, human action is defined by power relations, and pre-dating Foucault's argument that 'power is exercised only over free subjects' (Foucault, 1982: 221), he argues that a power relation can only occur if one party does not have total control over another. In such situations, there exists a power 'game' where 'the participants always have control "over each other"' (Elias, 1970: 81, original emphasis), and in consequence are also always to some extent dependent on each other. This also means that over the long term it is difficult for any one individual or group to 'determine history' because their intentions and actions are always likely to be moderated by others on whom they are dependent. Particularly within modern democracies there is unlikely to be any simple relation between a particular 'strategy' and a particular 'outcome', because any outcome represents the 'interweaving of countless individual interests and intentions' (1994: 389, added emphasis). In consequence, 'something comes into being that was planned and intended by none of these individuals, yet has emerged nevertheless from their intentions and actions' (Elias 1994: 389). In societal terms, this means that linear attempts to plan, say, 'ecocentric society' are likely to be nothing if not problematic. 'Planners' are always likely to have their ambitions moderated. 
If, as Zygmunt Bauman (1992) asserts, the search for order represented the basic project of modernity, then following Elias, it is one that was bound to fail because power relations are rarely about total control, but instead represent the interweaving of interdependencies between actors. As Elias argues, 'Underlying all intended interactions of human beings is their unintended interdependence' (Elias, 1969: 143, quoted in Kilminster, 1991: 101). The problems of car use provide a striking ecological metaphor here. Cars were intended to deliver a previously undreamt of personal mobility. Yet they have also delivered traffic jams, air and noise pollution etc. as a consequence of the unintended interdependence of millions of 'autonomous' car users. As people now have to drive to work or to the shops, 'travelling therefore becomes more necessary ... or alluring ("running away from it all", even for a few days holiday) than ever before, while becoming at the same time more difficult and exhausting' (Bauman, 1990: 188). The unintended consequence of car use thus becomes the increased necessity of travelling, and the difficulty of so doing as millions of interdependent autonomous drivers exercise their right to automobile transport.

In a similar vein, any attempt to create a new eco-order will be interwoven with the actions of a global network of actors. Yet it is difficult to predict the actions of others in this global network or how a particular eco-strategy will interweave with those actions. The language of such interdependency networks is not likely to be that of deliberately realized ecological plans but one of 'fertilization', 'mutation', 'amputation' or 'elimination' as such plans interweave with those of a vast array of others.

Such difficulties of eco-ordering are generally not sufficiently addressed within the current green organizational literature ${ }^{\mathrm{ii}}$. However there are theoretical frameworks available that do offer organizational researchers some purchase on these issues. One such is the actor-network theory associated with Michel Callon, Bruno Latour and John Law, particularly Callon's work on 'techno-economic networks' (1991: 132). Another comes from the wide-ranging studies of Elias. There are distinct similarities between both these theoretical perspectives: as John Law notes, 'the explanatory attitude of [actor- 
network] writers is not so different from that of Norbert Elias' (1994: 113). Both contain argument that resists epistemological categorization through labels such as modernist/postmodernist (Law, 1994; Latour, 1999a; Newton, 1999). With both, there is an emphasis that agency is best viewed from the perspective of interdependency networks, whether that of a single organization or the dense, complex and global interdependencies surrounding environmental degradation. In consequence, I shall refer to the points where their theoretical orientation overlaps as an interdependency network perspective $e^{\mathrm{iii}}$.

Central to this perspective is a questioning of the traditional conceptualization of the actor. For instance, a common view of the actor within traditional management literature is one who is self-contained, sovereign and autonomous, and whose thoughts, feelings and actions can be treated as relatively independent of the networks in which they operate (see Newton, 2001a). From this stance, we just need to know that a key actor such as a chief executive has been converted to the green cause, not how or why. There is also an assumption that such actors will semi-automatically act as powerful green agents, 'lightning rods for environmental actions' (Shrivastava, 1996: 188). The work of Elias and Callon however seriously question this view of the 'independent' actor because it obscures the need to attend to the way in which 'outcomes' - such as the decision of a chief executive to 'go green' - reflect a complex interweaving of interdependencies amongst people, a 'networked agency'. For instance, in understanding the actions of 'visionary' green organizational leaders (Kaczmarski and Cooperrider, 1999), we firstly need to explore the networks through which business leaders become enrolled as 'green' strategists. Secondly, we need to understand the interdependency networks through which they can translate others in the organization into 'greening agents'. If we follow Elias and Callon, understanding this process means attending to the interdependencies between actors inside and outside the organization - and in so doing, shifting our attention from the traditional image of the individual (and organization) as a 'closed box', or what Elias (1970, 1991) calls 'Homo clausus'. 
Elias argues that the portrayal of the actor as a 'closed box' is a common yet limiting assumption of much of the social sciences, especially psychology. He argues instead for a recognition of people as Homines aperti, which represents a vision:

'.. of people in the plural; we obviously need to start out with the image of a multitude of people, each of them relatively open, interdependent processes' (1970: 121)

In understanding power and human agency, the focus is necessarily therefore on interdependencies and networks, rather than the decisions and actions of individual 'sovereign' actors. In addition, actor-network theory stresses the theoretical centrality of non-human actors, such as in the case of the Chernobyl nuclear power plant which became 'an uncontrolled and autonomous force ... an actor in its own right' (Callon, 1991: 142). Common to Elias and actor-network theory is the critique of the "person closed in on himself - homo clausus, to use Elias' expression' (Callon, 1999: 185, original emphasis).

The traditional, yet often tacit, assumption of Homo clausus draws attention away from the way in which environmental degradation occurs through complex interdependency networks. As David Goldblatt notes:

'..pollutants almost invariably come from many sources. Thus a collective danger from collective origins must be legally pursued through the fiction of the individual legal person or corporation' (1996: 167).

To the extent that legislation is based on Homo clausus, the sovereign individual or corporation, it becomes difficult to enforce a desired eco-order because environmental degradation is a quintessentially network phenomena. Pollution might be contained if it were 'independent': the problem is that pollutants interweave with a range of other natural processes and thereby become difficult to control. In consequence, unless we acknowledge the networked form of agency - Elias's Homines aperti - we will have difficulty in dealing with environmental risk and degradation. As Orssatto and Clegg 
(1999) argue, 'a shift to greener strategies ... is not the effect of a singular agency, no matter how powerful' (1999: 274). This is not to suggest that individuals or groups, human or non-human, have no influence but rather that their actions may be amplified, modified, subverted or erased as they interweave with the actions of other 'players'.

What does all this imply for green organization studies? It suggests that this field requires more than evangelical imploration that things 'must' change, because ecologically speaking, they 'have to', or the uncritical application of existing organizational change rationales such as that of culture change (see above). Instead, researchers need to explore how the existing 'order' is created. In relation to Elias, we need to analyze the geometry and strength of the interdependencies that surround particular industries. In Callon's terms, we need to examine how human and non-human networks align, converge, and become standardized around processes that encourage environmental degradation ${ }^{\text {iv }}$. To undertake either of these projects, it is necessary to move beyond the often pre-conscious conceptualization of the actor as Homo clausus.

I shall now turn to the implications of these interdependency network perspectives for the greening of organizations. In particular, do they suggest a change of approach, and if so, what might this look like?

\section{GREENING AND NETWORKS}

In what follows, it is important to remember that we are developing a research perspective rather than outlining a finely defined research platform. The latter is not possible because we currently lack sufficient application of Elias and actor-network theory to green organization studies. In addition, actor-network theorists are generally resistant to the closure implied by standardized research platforms or research 'factories' (Latour, 1999b). 
One way of approaching the interdependency network perspective is to explore how it challenges current rationales for the greening of organizations. For instance, an assumption witnessed within a range of green organizational literature is that organizations should strive, as far as possible, to translate all their employees into 'green employees' through HRM or culture change programs (see above). Yet an interdependency network perspective questions this assumption because it begs the question of whether one needs such 'saturated' green networks in order for organizations to become aligned around green issues. Recent research by Andrew Crane (2000) suggests that 'green organizations' do not require such total employee commitment. Crane found that organizations that were clearly associated with a green 'mission' did not generally have staff who were committed to the 'green cause' and furthermore they 'exhibited little success in promoting and sustaining a company-wide environmental ethic' (2000: 691). Crane's research 'clearly calls into serious question the "deep ecology" prescriptions ... which suggest that only through a fundamentally moralized business culture can radical greening possibly take place' (Crane, 2000: 691). In a similar fashion, Ken Green, Barbara Morton and Steve New found that those responsible for promoting green procurement and purchasing did 'not necessarily [have] a keen personal commitment to environmental issues' (2000: 219). Instead, their research indicated that 'green procurement careerists' often pursued green agendas for 'personal or organizational agendas' other than a commitment to the green cause (2000: 219). Taken together, the research of Crane (2000) and Green et al (2000) suggest that it is neither easy to create green corporate cultures, even for 'green mission' companies, or necessary. In consequence, it questions current arguments for green corporate cultures and human resource management policies: if 'green mission' organizations can operate successfully without strong green cultures, why do we need green culture change? Instead it may be more profitable to research the minimal interdependency network that is necessary to sustain greener organizations. In practical terms this means researching the interdependency 'webs' through which green market or regulatory demand is translated inter-organizationally and intra-organizationally. Yet these are areas where we still lack sufficient research. As Green et al note: 
'.. the exact mechanisms inside organizations by which demand signals are received, understood by marketing and (where applicable) R\&D departments, and then translated into practical innovative product or process development have been relatively unexplored' $(2000: 219)$

As Green et al. (2000) add, there can be considerable variability in the ways in which organizational greening is currently supported. For example, in relation to greener purchasing decisions they found that one 'green' company used a committee, another had created a 'separate departmental body' to analyze the 'green credentials of suppliers', while yet another had 'an intricate web of influencing bodies and parties to the purchasing process' (Green et al, 2000: 218, added emphasis). The advantage of the work of Elias and Callon is that they direct attention to such variety of interdependency 'webs'/networks. They can be used to examine how the interdependencies between the technologies and personnel of purchasing, sales, marketing, and R\&D affect an organization's ability to translate 'green demand' into greener products. For instance, Elias (1970, 1994) draws our attention to the asymmetries within interdependency networks. This emphasis begs questions such as the following: does the 'junior' 'service' role of purchasing departments limit their ability to advance greener practices within organizations? Does it also limit the extent to which they can influence the sales departments of their suppliers? Through focusing on such interdependencies, Elias and Callon highlight organizational networks and the ways in which they variously advance or impede the greening of organizations and their products and services.

This orientation presents a contrast to that still popular amongst ecocentrism and other eco-philosophies. As Dryzek notes, much eco-philosophy assumes that eco-change will happen through education by 'an enlightened vanguard educating everyone else in how to think and behave in an environmentally sound fashion' (1996: 30-31). Within organizational literature, this can be witnessed in the somewhat imperial ambitions of culture change programs and among ecocentric writers who assert that 'environmental strategy must therefore begin with real commitment on the part of the whole organisation' (Welford, 1995: 11, added emphasis). Yet such mass green 'education'/'conversion' is unlikely. At the same time, an interdependency network 
perspective questions whether it is necessary (see above). Instead, following Callon (1991) and research such as that of Crane (2000) and Green et al. (2000), the question becomes how a convergent network can occur between salient actors - such as that between human skills and the texts and technologies involved in purchasing, sales, marketing and R\&D. To the extent that learning follows action (Weick, 1987), the formation of such convergent green networks may well precede any 'green conversion' rather than follow it as a range of eco-philosophy assumes (Dryzek, 1996). In other words, Weick's critique suggests that a major limitation of ecocentrism (and some other eco-philosophy) is the adoption of an outdated model of learning. Instead of 'green education' preceding 'green action', it appears more likely that it would accompany or follow such action. To put this another way, a 'revolutionary shift in paradigm' (Purser et al., 1995) is unlikely to be built from moralistic education alone, no matter how evangelical its rhetoric.

The question of course still remains as to how sufficient networks can be sustained to support green issues. A greener network is likely to involve a host of different actors such as scientists, governmental and inter-governmental agents, clean technologies, audit mechanisms and a range of texts, technologies and personnel. The problem is how to make this heterogeneous network converge. Callon (1991) notes that a convergent network is one where there is strong agreement between the key actors involved. A convergent network does not however mean:

'that everyone does the same thing, for networks usually include a range of complementary actors - for instance, scientists, technologists, entrepreneurs, salespersons and customers. Rather it points to the way in which the activities of actors fit together despite their heterogeneity ... Thus in a convergent network, faced with an angry client, the salesperson immediately knows which engineer to call and how to describe the problem so that the engineer can work on it' (1991: 148 , added emphasis).

If we follow Callon, a range of factors will shape network convergence. For instance, it is likely to be affected by rules of engagement, such as government regulations encouraging 
clean technology, environmental audit, 'green' contract compliance etc., or the cultural custom to comply with, or resist, government legislation. In addition, network convergence will be influenced by the degree of standardization within a network (Callon, 1991). A truly standardized green network would be one where all actors followed standard green procedures such as the use of renewable energy supplies, waste minimization, clean technology etc.

However Callon notes that 'strongly convergent networks only develop after long periods of investment, intense effort, and coordination' (1991: 148). From this perspective the problem for the green cause is that we are a long way from this kind of order. Nevertheless examples exist where convergent green networks have been successfully created. One such comes from greener alternatives to automobiles, such as that of the light electric vehicle (LEV). In order to persuade people to use this 'greener technology', it is necessary to build a convergent network around it. The 'Mendrisio' project in Switzerland provides an example of such a network, based on an aligned network of LEV technology, manufacturers, dealers, components, recharging stations, maintenance techniques and facilities etc. This network alignment and convergence enabled an ease of use and maintenance for the LEV driver and thereby aided the effectiveness of the Mendrisio project (Harms and Truffler, 1998; Orssatto and Clegg, 1999).

Yet there remain major challenges in maintaining such network convergence. As Callon (1980, 1986a) shows in his study of LEV development in France, building a convergent green technology network is highly problematic because of the diverse array of actors which may be involved (academics, local and national government agencies, technologies such as fuel cells and technical procedures). At the same time, greener networks are likely to remain fragile given that they often exist within global networks which are geared around environmentally degrading processes (Gray, 1999). In the case of the Swiss Mendrisio project, LEV networks remain reversible to the extent that they exist within strongly aligned networks based on the Fordist production of automobiles driven by internal combustion engines (ICEs), and all steel car bodies. Furthermore, as Renato 
Orssatto and Stewart Clegg observe, the development of greener automobiles is constrained by "the difficulties of breaking the "lock-in" situation created around the automobile system' (1999: 264). Central to this system are strongly convergent networks of ICEs, car components, manufacturers, supply procedures and suppliers, petroleum technologies and companies, gasoline stations, garages, dealerships etc. Changing the environmentally degrading automobile technology means analyzing such interdependent networks. For instance, a shift away from ICEs would impact the network of petroleum technologies and companies, gasoline stations, garages, components and suppliers. Any 'eco-change' strategy therefore has to be cognizant of the challenges of disentangling and re-working interdependency networks that are highly convergent, if not irreversible (Callon, 1991).

Standardization within the automobile industry also constrains alternative greener technology, such as LEVs. The latter fall short when compared to existing standards, particularly in relation to maximum speed and the distance that can be traveled before recharging becomes necessary. In Callon's (1991) terms, the current industry is characterized by strong elements of standardization that strengthen its network coordination and convergence. Greener alternatives are likely to be judged in relation to these standards (Hart, 1997). This may in part explain why 'to date, most experiments with alternative transport technologies have been rather small and have covered a short period of time' (Kemp, Schot and Hoogma, 1998: 192). In sum, though effective alternative green technology is possible, it has to contend with the reinforcement of network convergence that standardization affords the current automobile industry.

What is the relevance of the above argument for green organization studies? Firstly, it suggests that we need to re-appraise existing eco-change rationales such as green culture change, and the model of learning upon which they implicitly rely. The ecocentric call to convert all to the green cause may be neither achievable, nor necessary. Instead, it may be more productive to study how and why interdependent networks converge. Although there is no clear program to deliver a greener world, this does not detract from the 
potential benefits of studying green network formation. Though in need of further application, Elias and actor-network theorists such as Callon provide a range of concepts that are directly relevant to such analysis. Callon's (1991) arguments are particularly interesting because they address the processes through which greener products or services move beyond the stage of 'fragile' networks and gain a measure of stability through network alignment, coordination and convergence. Some relevant research examples do already exist, as with the studies of LEV networks provided by Callon (1980, 1986a), Harms and Truffler (1998), Kemp et al., (1998), and Orssatto and Clegg (1999). As the example of the automobile industry however suggests, we also need to examine the network convergence that currently supports environmentally degrading industrial processes if we are to understand the challenge of greening them. In sum, research is likely to be most productive where it simultaneously explores network convergence processes that surround environmentally degrading activities and alternative greener processes. 


\section{GLOBALIZATION AND NETWORKS}

The problems of eco-reordering are further highlighted when we examine global interdependency networks. Though a detailed discussion of globalization is beyond the scope of the present article, it is nevertheless worth attending to some of the implications of global analysis. It is difficult to ignore the global dimension because environmental degradation is not contained within either national or continental boundaries (Yearley, 1996): global warming is 'global'.

Not surprisingly, ecocentric and deep ecology writers have addressed globalization issues, particularly its potential to advance or constrain their dreams of a greener world. For example, Arne Naess argues that in order to green the globe, 'occasional coercion' will have to be used with developing countries that seek to follow the West's history of environmentally degrading industrialization (Naess, 1995c: 449). Naess suggests that the rationale for such 'coercion' should be the 'application of the norm of universalizability' based on the argument that 'if ecological sustainability is a necessity for any area, then it is a necessity for all areas' (1995c: 449). Yet there remain serious ethical questions about such desires because it is difficult to 'wash out' the image of neo-colonialism which they engender. In addition, the central question remains as to how universal global green norms are to be enforced. In Callon's (1991) terms, such network alignment and standardization represents a supreme challenge when undertaken at the global level. It is very difficult to establish global ecological agreements, as illustrated by the resistance of developing countries to neo-colonial coercion at Rio, Kyoto and Bonn. Furthermore, it is not easy to 'police' such agreements. As Yearly notes:

'.. in the absence of a global authority, countries have to consent to work together [and] ... bargain until an approach is agreed. Most countries can be relied upon to approach these negotiations selfishly, wanting to secure as advantageous a deal for themselves as possible. The monitoring of agreements can also be costly, and countries are unlikely to want to spend more than the minimum on civil servants and scientists to check that they are sticking to the agreed measures' (1996: 62; cf., Parker, 1996). 
The case of fishing provides one documented example of the difficulties of global green policing. There is firstly the problem that fish do not respect national boundaries (relating to agreed fish quotas etc.), and secondly that policing fish catches is both difficult and likely to be undertaken with varying degrees of national enthusiasm (Peterson, 1993; Yearley, 1996). In Callon's (1991) terms, neither fish nor human will align within a convergent network. Such 'tragedies of the commons' are therefore not easily controlled even when international agreements are attained.

Such observations again underline how the problematic of order remains central to the ecological dilemma. In relation to Elias and Callon, they emphasize the challenges of building global green networks. Firstly they suggest that such networks are currently characterized by what Callon calls weak coordination because they 'have no specifically local rules' (Callon, 1991: 147) ${ }^{\mathrm{v}}$. On the one hand, the Bonn agreement is a further step toward global network coordination, albeit that it represents a watered down version of the Kyoto protocol that, critically, lacks U.S. involvement. On other hand, the Bonn agreement may have limited impact at a local level, particularly in developing countries. Secondly, there is some evidence that global networks are becoming less convergent (Callon, 1991). As Waters notes, the development of instantaneous globalized information technology and the dedifferentiating of financial markets means that 'the entire system has become more difficult to control' (Waters, 1995: 88). As Waters adds:

'States are placed at the mercy of financial markets - the collapse of the European Monetary System in 1992 was the consequence of persistent market attacks on its weaker elements, for example. All the power of the Bundesbank could not save it' (1995: 88)

As Orssatto and Clegg also suggest, if global financial markets 'are largely beyond the control of national or international authorities', this also means that 'ecological threats ... are not adequately dealt with' (1999: 266). 
The obvious solution to this dilemma is to further pursue global interdependent networks to limit environmental degradation. Yet as Barbara Gray (1999) notes, this is a tortuous journey. In the first place, there are doubts as to the efficacy of current international agencies. As Zimmerman observes, critics such as Gary Snyder and Gus diZerega argue that 'calling for the United Nations or some other centralized organization to protect the planet is like inviting foxes to guard the henhouse' (Zimmerman, 1994: 330). In the second place, attempts to reach global agreements have been hampered either because 'advanced industrialized nations were unwilling to accept concessions (Gray, 1999: 205) or because of mistrust between the parties (as witnessed recently in negotiations at The Hague).

Such difficulties might be seen as just a temporary problem that can be resolved over time. Yet such optimism is countered by the argument that it may be hard to unravel networks that currently support environmental degradation, particularly as many are strongly convergent (see above). In addition, we must consider whether we are moving toward global disorder rather than order. Kyoto and Bonn do represent a strengthening of global network coordination, and to that extent, an eco-ordering. Yet we must also remember that many writers on globalization argue that cultural heterogeneity and 'hybridization' represent the trend of globalization rather than the homogeneity implicit in a new 'world order'. For these writers, visions of a new world order often represent an unwarranted and triumphalist Western myth that detracts from growing global heterogeneity. This applies both to writers who emphasize the cultural hybridization of globalization processes (e.g., Nederveen Pieterse. 1995), and to those who stress the salience of global 'systems' (e.g., Friedman, 1992, 1995). As Barbara Parker (1996) notes, there is wide global variety in ethical codes. As she comments, 'what is bribery in one country might be viewed as standard business practice in another' (1996: 498). Such observation suggests that a single world order is presently unlikely, whether cultural, economic or ecological. 
What does the above imply for green organizational research? Firstly it suggests that a green perspective necessarily draws attention to inter-organizational and global networks as well as intra-organizational networks. Secondly it underlines the challenge of both formulating and policing global green agreements. In Callon's (1991) terms, there is likely to be weak network co-ordination. Thirdly it emphasizes the difficulties of standardizing green practice at local levels around the world. If there is one universal norm, it may be localized hybridity and variation in ethics and practice rather than global uniformity. 


\section{CONCLUSION}

Green organizational writers need to recognize the immense challenge of re-ordering organizations and societies. Eco-ordering involves a vast array of global actors whose actions are likely to interweave with one another in ways that may be difficult to predict or control (Elias, 1994). At the same time, the representation of 'nature' is problematic (e.g., Soper, 1995), and the solution of environmental degradation is seriously disputed by environmental versus industrial groupings, by social and life scientists, by governments (e.g., of the 'North' vs. the 'South') etc. Given such contestation, and the wide variety of actors involved, it is difficult to predict the form of any future global eco-ordering. It is not that eco-ordering is futile or that all need be 'gloom and doom'. Yet we need to recognize that eco-strategies are unlikely to be realized quite as intended.

So how can organizational research aid our understanding? I would suggest that there is a need to move beyond the theoretical constraints that sometimes circumscribe this field. Firstly, this requires a critical approach to ecocentric argument because its representation of nature and its eco-change rationales are open to question. Secondly, researchers need to acknowledge the interdependencies of natural and social processes, a perspective that challenges the image of Homo clausus and draws attention to the networked character of human and non-human agency. It seems strange that although green organizational writers increasingly emphasize the interdependent nature of environmental responsibility, they still tend to implicitly employ notions of autonomous independent actors. Thirdly, I have argued that the work of Elias, and actor-network theorists such as Callon, provide one framework relevant to environmental degradation and the development of greener alternatives. It has not however been my intention to suggest that this is the only vehicle for such analysis. In particular this framework requires further development through application to green organization studies. Yet notwithstanding such constraints, an interdependency network perspective offers (1) an alternative theoretical reading, (2) a potentially promising basis for research analysis and (3) a progression beyond the

limitations of current green organizational prescription. With the first, it questions ecocentric prescriptions for, say, green culture change because these may be neither 
realistic nor necessary for a convergent green network (see above). With the second, the work of Elias and Callon provide a range of concepts through which to begin to analyze the difficulties of green network convergence such as those associated with greener technology. With the third, Elias and Callon provide an avenue that diverts energy away from the indiscriminate application of conventional management prescription (see above) and toward a consideration of how greener networks are constrained or sustained.

It is important to emphasize that I have only skimmed the surface in terms of the potential relevance of writers such as Elias and Callon to green organization studies. For example, the work of Callon, and other actor-network theorists such as Latour and Law, are also of interest because of the way in which they try to traverse the traditional dualism between 'nature' and 'society' (e.g., Callon and Latour, 1992; Latour, 1999a, 1999b), and attend to the non-human actor as much as the human. In addition, they provide a variety of other concepts relevant to greening networks (such as 'enrolment', 'mobilization', 'translation', 'intermediaries', 'punctualization'; e.g., see Callon, 1986b, 1991). Similarly, as Victor Roudometof and Roland Robertson (1995) note, Elias's work is of particular relevance to globalization issues because of its potential to work at both micro and macro-analytical levels (Newton, 2001a). Further detailed discussion of Elias, and his relevance to organization theory and analysis, is contained in a recent special issue of the journal, Organization (Newton, 2001b).

Finally, I wish to stress that, although I have been critical of the current field, I do not mean to imply that all existing work is flawed or of limited value. There are interesting applications such as the use of neoinstitutional theory, particularly so where writers address the difficulties of neoinstitutional theory in tackling issues of agency and change (DiMaggio, 1988; e.g., Clark and Jennings, 1997; Hoffman, 1999). Equally, there is a growing body of stimulating work that is sympathetic to critical theory in the tradition of, say, Marx, Gramsci or the Frankfurt School (e.g., Levy, 1997; Burkett, 1997, Fox, 1997; Foster, 1997). This critical tradition underlines the fact that it is not necessarily 'in everybody's interest to bring about a sustainable and egalitarian society' (Dobson, 1990: 152, see above $)^{\mathrm{vi}}$. Lastly, there are also some more thoughtful reviews (e.g., Egri and 
Pinfield, 1996) as well as work that is of particular benefit in addressing the global dimensions of greening (e.g., Parker, 1999). The challenge is to use this varied theoretical resource to understand current networks of environmental degradation and the possibility of their realignment around networks that move, however haphazardly, toward the enhancement of the natural environment. 


\section{REFERENCES}

Adam, Barbara (1998) Timescapes of Modernity: The Environment and Invisible Hazards. London: Routledge.

Alvesson, Mats and Willmott, Hugh (1995) Strategic management as domination and emancipation: From planning and process to communication and praxis. In Paul Shrivastava and Charles Stubbart, Advances in Strategic Management, Vol. 12A. Greenwich. Connecticut: JAI Press.

Alvesson, Mats and Willmott, Hugh (1996) Making Sense of Management. London; Sage.

Anderson, Lynne M. and Bateman, Thomas S. (2000) Individual environmental initiative: Championing natural environmental issues in U.S. business organizations. Academy of Management Journal, 43 (4): 548-570.

Anthony, Peter D. (1994) Managing Culture. Milton Keynes: Open University Press.

Bansal, Pratima and Roth, Kendall (2000) Why companies go green: A model of ecological responsiveness. Academy of Management Journal, 43 (4): 717-736.

Barry, David and Elmes, Michael (1997) Strategy retold: Toward a narrative view of strategic discourse. Academy of Management Review, 22 (2): 429-452.

Bate, Roger (1998a) (ed.) Global Warming: The Continuing Debate. Cambridge: The European Science and Environment Forum.

Bate, Roger (1998b) The politicisation of climate science. In Roger Bate (ed.), Global Warming: The Continuing Debate. Cambridge: The European Science and Environment Forum.

Bauman, Zygmunt (1990) Thinking Sociologically. Oxford: Blackwell

Bauman, Zygmunt (1992) Intimations of Postmodernity. London: Routledge.

Bauman, Zygmunt (1997) Postmodernity and its Discontents. Cambridge: Polity.

Beaumont, John R., Pedersen, Lene M. and Whitaker, Brian D. (1993) Managing the Environment: Business Opportunity and Responsibility. Oxford: Butterworth: Heinemann.

Beck, Ulrich (1992) Risk Society: Towards a New Modernity (trans. Mark Ritter). London: Sage. 
Benton, Ted (1994) Biology and social theory in the environmental debate. In Michael Redclift and Ted Benton, Social Theory and the Global Environment. London: Routledge.

Bhargava, Sangeeta and Welford, Richard (1996) Corporate strategy and the environment: The theory. In Richard Welford (ed.), Corporate Environmental Management: Systems and Strategies. London: Earthscan, pp. 13-32.

Bookchin, Murray (1994) Which Way for the Ecology Movement. AK Press: San Francisco.

Bradford, George (1989) How Deep is Deep Ecology? Ojai, California: Times Change Press.

Brown, L. David (1991) Bridging organizations and sustainable development. Human Relations, 44 (4): 807-831.

Burkett, Paul (1997) Nature in Marx reconsidered. Organization \& Environment, 10 (2): 164-183.

Burkitt, Ian (1999) Bodies of Thought. London: Sage.

Callenbach, Ernest, Capra, Fritjof, Goldman, L., Lutz, R. and Marburg, S. (1993). EcoManagement: The Elmwood Guide to Ecological Auditing and Sustainable Business. San Francisco: Berret-Koehler.

Callon, Michel. (1980) The state and technical innovation: a case study of the electrical vehicle in France. Research Policy, 9: 358-376.

Callon, Michel (1986a) The sociology of an actor-network: The case of the electric vehicle. In Michel Callon, John Law and Arie Rip (eds.), Mapping the Dynamics of Science and Technology: Sociology of Science in the Real World. Basingstoke: Macmillan.

Callon, Michel (1986b) Some elements of a sociology of translation: domestication of the scallops and the fishermen of St Brieuc Bay. In John Law (ed.), Power, Action and Belief: A New Sociology of Knowledge? London: Routledge and Kegan Paul.

Callon, Michel (1991) Techno-economic networks and irreversibility. In John Law (ed.), A Sociology of Monsters? Essays on Power, Technology and Domination, Sociological Review Monograph 38. London: Routledge. 
Callon, Michel (1999) 'Actor-network theory - the market test', in John Law and John Hassard, Actor Network Theory and After. Oxford: Blackwell/The Sociological Review, pp. 181-195.

Callon, Michel and Latour, Bruno (1992) Don't throw the baby out with the Bath School!: A reply to Collins and Yearley. In Andrew Pickering (ed.), Science as Practice and Culture. Chicago: University of Chicago Press.

Capra, Fritjof (1995) Deep ecology: A new paradigm. In George Sessions (ed.), Deep Ecology for the Twenty-First Century. Boston, Mass.: Shambala Publications.

Cheney, Jim (1989) The neo-Stoicism of radical environmentalism. Environmental Ethics, 11 (4): 293-325.

Clark, Vivien and Jennings, P. Devereaux (1997) Talking about the natural environment: A means for desinstitutionalization? American Behavioral Scientist, 40 (4): 454-464.

Cooperrider, David L. and Khalsa, Gurudev S. (1997) The organization dimensions of global environmental change. Organization and Environment, 10 (4): 331-341.

Crane, Andrew (2000) Corporate greening as amoralization. Organization Studies, 21 (4): 673-696.

Darier, Eric (1999) Foucault and the environment: An introduction. In Eric Darier (ed.), Discourses of the Environment. Oxford: Blackwell.

Deal, Terrence A. and Kennedy, Allen A. (1988) Corporate Cultures: The Rites and Rituals of Corporate Life. Harmondsworth: Penguin

Devall, Bill and Sessions, George (1985) Deep Ecology: Living as if Nature Mattered. Layton, UT: Peregrine Smith Books.

DiMaggio, Paul (1988) Interest and agency in institutional theory. In Lynne G. Zucker (ed.) Institutional Patterns and Organizations. Cambridge, MA: Ballinger, pp. 3-21.

Dobson, Andrew (1990) Green Political Thought: An Introduction. London: Unwin Hyman.

Dryzek, John S. (1996) Foundations for environmental political economy: The search for Homo Ecologicus? New Political Economy, 1 (1): 27-40.

Easterbrook, Gregg (1996) A Moment on the Earth. Harmondsworth: Penguin. 
Egri, Carolyn P. and Pinfield, Lawrence T. (1996) Organizations and the biosphere: Ecologies and environments. In Stewart R. Clegg, Cynthia Hardy and Walter R. Nord (eds.), Handbook of Organization Studies. London: Sage.

Elias, Norbert (1969) Psychiatry in a Changing Society. London: Tavistock.

Elias, Norbert (1970) What is Sociology? New York: Columbia University Press.

Elias, Norbert (1991). The Society of Individuals. Oxford: Blackwell.

Elias, Norbert (1994). The Civilizing Process, Vols. 1 and 2. Oxford: Blackwell.

Elkington, John and Burke, Tom (1987). The Green Capitalists. London: Victor Gollancz.

Fischer, Kurt and Schot, Johan (1993) (eds.) Environmental Strategies for Industry. Washington, D.C.: Island Press.

Foster, John Bellamy (1997) The crisis of the earth: Marx's theory of ecological sustainability as a nature-imposed necessity for humn production. Organization \& Environment, 10 (3): 278-295.

Foucault, Michel (1982) Afterword: The subject and power. In H.F. Dreyfus and Paul Rabinow (eds.), Michel Foucault: Beyond Structuralism and Hermeneutics. Brighton: Harvester Press

Fox, Julia D. (1997) Leasing the ivory tower at a social justice university: FreeportMcMoRan, Loyala University, and corporate greenwashing. Organization \& Environment, 10 (3): 259-277.

Friedman, Jonathan (1992) General historical and culturally specific properties of global systems. Review, 15 (3): 335-372.

Friedman, Jonathan (1995) Global system, globalization and the parameters of modernity. In Mike Featherstone, Scott Lash and Roland Robertson (eds.), Global Modernities. London: Sage.

Gladwin, Thomas N., Kennelly, James J. and Krause, Tara-Shelomith (1995) Shifting paradigms for sustainable development: Implications for management theory and research. Academy of Management Review, 20 (4): 874-907.

Glendinning, Chellis (1995) Recovery from western civilization. In George Sessions (ed.), Deep Ecology for the Twenty-First Century. Boston, Mass.: Shambala Publications.

Goldblatt, David (1996) Social Theory and the Environment. Cambridge: Polity. 
Gore, Al (1992) Earth in the Balance: Forging a New Common Purpose. London: Earthscan.

Gray, Rob, Bebbington, Jan and Walters, Diane (1993). Accounting for the Environment. London: Paul Chapman Publishing.

Gray, Barbara (1999) The development of global environmental regimes: Organizing in the absence of authority. In David L. Cooperrider and Jane E. Dutton (eds.) Organizational Dimensions of Global Change: No Limits to Cooperation. Thousand Oaks, Calif.: Sage.

Green, Judith (1995) Retrieving the human place in nature. Environmental Ethics, 17 (4): 381-396.

Green, Ken (2000) Greening organizations: Purchasing, consumption and innovation. Organization \& Environment, 13 (2): 206-225.

Hansen, J., Sato, M., Lacis, A. and Ruedy. R. (1997) The missing climate forcing. Phil. Trans. R. Soc. London B, 352: 231-240.

Hardy, Cynthia (1995) Managing strategic change: power, paralysis and perspective. In Paul Shrivastava and Charles Stubbart, Advances in Strategic Management, Vol. $12 B$. Greenwich. Connecticut: JAI Press.

Harms, S. and Truffer, B. (1998) The Swiss Large Scale Experiment with Lightweight Electric Vehicles. Internal report for the European Commission, DG XII, RTD programme, Environment and Change, Human Dimensions of Environmental ChangeStrategic Niche Management Project. Brussels: European Commission.

Hart, Stuart L. (1997). Beyond greening: Strategies for a sustainable world. Harvard Business Review, January-February, pp. 65-76.

Hart, Stuart L. (1999) Corporations as agents of global sustainability: Beyond competitive strategy. In David L. Cooperrider and Jane E. Dutton (eds.) Organizational Dimensions of Global Change: No Limits to Cooperation. Thousand Oaks, Calif.: Sage.

Hettinger, Ned and Throop, Bill (1999) Refocusing ecocentrism. Environmental Ethics, 21 (1): 3-21.

Hoffman, Andrew J. (1999) Institutional evolution and change: Environmentalism and the U.S. chemical industry. Academy of Management Journal, 42 (4): 351-371.

Hutchinson, Colin (1992) Corporate strategy and the environment. Long Range Planning, 25, (4): 4 \& 9-21. 
Jennings, P. Devereaux and Zandbergen, Paul A. (1995) Ecologically sustainable organizations: An institutional approach. Academy of Management Review, 20 (4): 10151052.

Jones, David and Welford, Richard (1997) Organizing for sustainable development: Structure, culture and social auditing. In Richard Welford (ed.), Hijacking Environmentalism: Corporate Responses to Sustainable Development. London: Earthscan.

Kaczmarski, Kathryn M. and Cooperrider, David L. (1999) Constructionist leadership in the global relational age: The case of the Mountain Forum. In David L. Cooperrider and Jane E. Dutton (eds.) Organizational Dimensions of Global Change: No Limits to Cooperation. Thousand Oaks, Calif.: Sage.

Kemp, Rene, Schot, Johan and Hoogma, Remco (1998) Regime shifts to sustainability through processes of niche formation: The approach of niche strategic management. Technology Analysis and Strategic Management, 10 (2): 175-195.

Kilminster, Richard (1991) Structuration theory as world-view. In Christopher G.A. Bryant and David Jary (eds.), Giddens' Theory of Structuration: A Critical Appreciation. London: Routledge.

Knights, David and Morgan, Glenn (1991) Corporate strategy, organizations, and subjectivity: A critique. Organization Studies, 12 (2): 251-273.

Knights, David and Morgan, Glenn (1995) Strategy under the microscope: Strategic management and IT in financial services. Journal of Management Studies, 32 (2): 191214.

Kunda, Gideon (1992) Engineering Culture, Control and Commitment in a High-Tech Corporation. Philadelphia: Temple University Press.

Latour, Bruno (1999a) Pandora's Hope: Essays on the Reality of Science Studies. Cambridge, Mass.: Harvard University Press.

Latour, Bruno (1999b) On recalling ANT. In John Law and John Hassard, Actor Network Theory and After, pp. 15-25. Oxford: Blackwell/The Sociological Review.

Law, John (1994) Organizing Modernity. Oxford: Blackwell.

Levy, David L. (1997) Environmental management as political sustainability. Organization \& Environment, 10 (2): 126-147. 
Lockwood, David (1964) Social integration and system integration. In George K. Zollschan and Walter Hirsch (eds.), Explorations in Social Change. London: Routledge \& Kegan Paul.

Luke, Tim (1988) The dreams of deep ecology. Telos, No. 76: 65-92.

Mintzberg, Henry (1988) Beyond configuration: Forces and forms in effective organizations. In Henry Mintzberg et al (eds.) The Strategy Process. New York: Prentice Hall.

Mintzberg, Henry and Waters, James A. (1994). In Haridimos Tsoukas (ed.), New Thinking in Organizational Behaviour. Oxford: Butterworth-Heinemann, pp. 188-208.

Naess, Arne (1973) The shallow and deep, long-range ecology movement: A summary. Inquiry, 16: 95-100.

Naess, Arne (1992) 'Deep ecology for the $22^{\text {nd }}$ century. The Trumpeter, 9 (2): 53-60.

Naess, Arne (1995a) The deep ecology 'eight points' revisited. In George Sessions (ed.), Deep Ecology for the Twenty-First Century. Boston, Mass.: Shambala Publications.

Naess, Arne (1995b) The deep ecological movement. In George Sessions (ed.), Deep Ecology for the Twenty-First Century. Boston, Mass.: Shambala Publications.

Naess, Arne (1995c) Politics and the ecological crisis: An introductory note. In George Sessions (ed.), Deep Ecology for the Twenty-First Century. Boston, Mass.: Shambala Publications.

Nederveen Pieterse, Jan (1995) Globalization as hybridization. In Mike Featherstone, Scott Lash and Roland Robertson (eds.), Global Modernities. London: Sage, pp. 45-68.

Newton, Tim (1996) Agency and discourse: Recruiting consultants in a life insurance company. Sociology, 30 (4): 717-739.

Newton, Tim \& Harte, George (1997) Green business: Technicist Kitsch? Journal of Management Studies, 34 (1): 75-98.

Newton, Tim (1999) Power, subjectivity and British industrial and organizational sociology: The relevance of the work of Norbert Elias. Sociology, 33 (2): 411-440.

Newton, Tim (2001a) Organization: The relevance and the limitations of Elias. Organization, 8 (3): 467-495.

Newton, Tim (2001b) (ed.) Special issue: Elias and organization. Organization, 8 (3). 
Ogbonna, Emmanuel (1993) Managing organisational culture: fantasy or reality? Human Resource Management Journal, 3 (2): 42-54.

Orssatto, Renato J. and Clegg, Stewart R. (1999) The political ecology of organizations: Toward a framework for analyzing business-environment relationships. Organization \& Environment, 12 (3): 263-279.

Parker, Barbara (1996) Evolution and revolution: From international business to globalization. In Stewart Clegg, Cynthia Hardy and Walter R. Nord (eds.), Handbook of Organization Studies. London: Sage.

Peterson, M.J. (1993) International fisheries management. In Peter M. Haas, Robert O. Keohane and Marc A. Levy (eds.), Institutions for the Earth: Sources of Effective International Environmental Protection. London: MIT Press, pp. 249-305.

Porritt, Jonathon and Winner, David. (1988) The Coming of the Greens. London: Fontana.

Purser, Ronald E., Park, Changkil and Montuori, Alfonso (1995) Limits to anthropocentrism: Toward and ecocentric organizational paradigm. Academy of Management Review, 20 (4): 1053-1089.

Purser, Ronald E. (1997) From global management to global appreciation: A transformative epistemology for aperspectival worlds. Organization and Environment, 10 (4): 361-383.

Roudometof, Victor and Robertson, Roland (1995) 'Globalization, World-System Theory and the Comparative Study of Civilizations', in Stephen K. Sanderson (ed.), Civilizations and World Systems: Studying World-Historical Change, pp. 273-300. Walnut Creek, Calif.: AltaMira Press.

Sessions, George (1995a) Ecocentrism and the anthropocentric detour. In George Sessions (ed.), Deep Ecology for the Twenty-First Century. Boston, Mass.: Shambala Publications.

Sessions, George (1995b) Preface to George Sessions (ed.), Deep Ecology for the TwentyFirst Century. Boston, Mass.: Shambala Publications.

Shrivastava, Paul (1986) Is strategic management ideological? Journal of Management, 12 (3): 363-377.

Shrivastava, Paul (1995) Ecocentric management in a risk society. Academy of Management Review, 20 (1): 118-137. 
Shrivastava, Paul (1996) Greening Business: Profiting the Corporation and the Environment. Cincinnati, Ohio: Thompson Executive Press.

Smircich, Linda (1983) Concepts of culture and organizational analysis. Administrative Science Quarterly, 28 (3): 339-358.

Soper, Kate (1995) What is Nature? Oxford: Blackwell.

Srikantia, Param and Bilimoria, Diana (1997) Isomorphism in organization and management theory: The case of research on sustainability. Organization and Environment, 10 (4): 384-406.

Steiner, Stan (1976) The Vanishing White Man. New York: Harper and Row.

Waters, Malcolm (1995) Globalization. London: Routledge.

Welford, Richard (1995) Environmental Strategy and Sustainable Development: The Corporate Challenge for the 21st Century. London: Routledge.

Weick, Karl (1987) Substitutes for corporate strategy. In David Teece (ed.), The Competitive Challenge. Cambridge: Mass: Ballinger, pp. 222-233.

Whittington, Richard (1993) What is Strategy and Does it Matter? London: Routledge.

Willmott, Hugh (1993) Strength is ignorance; Slavery is freedom; Managing culture in modern organizations. Journal of Management Studies, 30: 515-552.

Yearley, Steven (1996) Sociology, Environmentalism, Globalization: Reinventing the Globe. London: Sage.

Zimmerman, Michael (1994) Contesting Earth's Future: Radical Ecology and Postmodernity. Berkeley: University of California Press.

\footnotetext{
${ }^{\mathrm{i}}$ This contestation is increasingly apparent following recent challenges to deep ecology and green orthodoxy (e.g., Easterbrook, 1996). In particular, a central tenet of current eco-orthodoxy, namely that global warming is proceeding apace, continues to be the subject of controversy amongst climatologists. Some argue that there is little clear evidence that global warming is a consequence of human activity rather than 'natural' cyclical variation, or else suggest that climatological complexity calls 'into question our ability to make any reliable projection of future global climate change' (Hansen et al., 1997: 239; cf., Bate, 1998a). As Bate notes, in constructing a seeming 'consensus', the general media and interest groups have selectively attended to climate modelers, ignoring or downplaying those who make climate 'predictions with the appropriate caveats and underlining the uncertainties' (1998b: x). One can however counter such climatological controversy by arguing that it is still far better to adopt the 'precautionary principle', and adopt 'eco-friendly' policies as a precaution against the likelihood that global warming is due to human action.

ii Organizational researchers do address related issues in work on strategy. Yet the limitation of current work on corporate environmental strategy is its tendency to rely on the idealized visions of order of classical strategy models and their 'dream of purity' (Bauman, 1997: 5) wherein corporate life is parceled
} 
into its 'proper' place, the boxes and arrows of the strategy model diagram. Many of the writers adopt a taxonomic approach close to the Darwinian category of 'lumpers' whose main desire is to 'have pigeonholed something into one box or another' (Mintzberg, 1988: 762). Companies are 'lumped' together according to the seriousness of the environmental orientation (e.g., Welford, 1995; Beaumont et al., 1993), or according to the kind of environmental strategy they do or can adopt (e.g., Bhargava and Welford, 1996). Although there is some modeling of organizational processes, these tend to remain stylized and idealized (e.g., Hutchinson, 1992). It remains surprising that the corporate environmental strategy literature has not given more attention to less 'linear' perspectives on strategy (e.g., Mintzberg, 1988, 1990; Weick, 1987) or to more critical orientations (e.g., Alvesson and Willmott, 1995; Barry and Elmes, 1997; Hardy, 1995;

Knights and Morgan, 1991; Whittington, 1993). However though these alternative approaches to strategy acknowledge its complexity, they raise a problem for the green endeavor because they emphasize the frailty of any strategy, whether corporate, environmental or ecological.

iii I use this term to refer to the label 'actor-network' associated with actor-network theorists, and the concept of figuration employed by Elias (1994). This is because it conveys what it is central to these theoretical orientations, namely an emphasis on interdependencies, and also because the term, 'interdependency network', is more immediately accessible than that of figuration. I should note however that it is beyond the scope of this article to provide a detailed illustration of the subtle nuances of either Elias or actor-network argument, or the latter's emphasis upon non-human agency. Instead, for the present, I must necessarily truncate or background much of their complexity, and focus on issues and concepts that are particularly relevant to eco-ordering. It should also be noted that there are significant differences between the argument of Elias and actor-network theory. For instance, as I have argued elsewhere (Newton, 1999), actor network theory is biased toward the analysis of the 'non-human' and the technological. In contrast, Elias tends to downplay the significance of tools and technology (Burkitt, 1999).

${ }^{\text {iv }}$ Such a project has similarities with those seeking to build coalitions of green actors (Brown, 1991; Gray, 1999; Hart, 1999) and those who suggest that green strategies require 'the formation of a new actor network (Kemp, Schot and Hoogma, 1998: 191). Yet it differs because the arguments of writers such as Elias and Callon imply a reevaluation of what we mean by the 'actor'.

'Callon uses the term, 'coordination', to refer to the 'codifying regulations' which 'rarefy' and constrain the development of actor-neworks (1991: 147). These can include rules ranging from 'written laws to customs' (1991: 146) that determine who or what counts as an actor in a network, such as who has a right to participation in global negotiations, as well as 'conventions about who may speak on behalf of whom' (1991; 146, original emphasis), such as state civil servants, industrial groupings or NGOs. Callon argues that there is likely to be strong coordination where a network is 'shaped by both local and general rules' and weak coordination where there are 'no specifically local rules' (1991, 147, original emphasis). The concept of coordination raises interesting questions and problems for the green project, such as who does or should count as an actor in WTO meetings, and whether general rules that emerge from global conventions will be implemented at local level.

${ }^{\text {vi }}$ To writers in the critical tradition, it may seem that the arguments made above are insufficiently radical, particularly in the advancement of an alternative agenda. This is because approaches such as that actornetwork theory, and especially Elias, point to the frailty of human (and non-human) endeavor, and the difficulty of reprogramming the world according to more enlightened criteria. Yet this does not mean critical theory is not relevant to the green agenda. 